\title{
Dihydrogen and Acetylene Activation by a Gold(I)/Platinum(0) Tran- sition Metal Only Frustrated Lewis Pair
}

\author{
Jesús Campos
}

Instituto de Investigaciones Químicas (IIQ), Departamento de Química Inorgánica and Centro de Innovación en Química Avanzada (ORFEO-CINQA). Universidad de Sevilla and Consejo Superior de Investigaciones Científicas (CSIC). Avenida Américo Vespucio 49, 41092 Sevilla (Spain).

\begin{abstract}
The first example of a Frustrated Lewis Pair (FLP) solely constructed around transition metal centers is described in this work. We have focused on the established capacity of $\mathrm{Au}(\mathrm{I})$ and $\mathrm{Pt}(\mathrm{o})$ complexes to act as Lewis acidic and basic fragments, respectively, while employing sufficiently bulky $\mathrm{P}^{t} \mathrm{Bu}_{3}$ and terphenyl phosphine ligands. This avoids formation of metallic Lewis adducts and confers the $\mathrm{Au}(\mathrm{I}) / \mathrm{Pt}(\mathrm{o})$ pair a remarkable capacity to activate dihydrogen and acetylene molecules in a fashion that closely resembles that of traditional main group FLP systems. As a consequence, unusual heterobimetallic Au(I)/Pt(II) complexes containing hydride $(-\mathrm{H})$, acetylide $(-\mathrm{C} \equiv \mathrm{CH})$ and vinylene $(-\mathrm{HC}=\mathrm{CH}-)$ bridges have been isolated.
\end{abstract}

The recent development of Frustrated Lewis Pairs (FLPs) has catapulted the chemistry of main group elements beyond its well-established limits, achieving reactivity patterns that were once restricted to transition metals (TMs). ${ }^{1}$ A prominent example with profound implications in metal-free catalytic hydrogenations, ${ }^{2}$ is the activation of dihydrogen by phosphine/borane pairs. Despite their importance, the catalytic usefulness of FLPs is nevertheless limited to mainly hydrogenation and a few other reactions, ${ }^{3}$ possibly as a consequence of the reluctance of main group elements to participate in electron-transfer and other fundamental organometallic reactions, which are key elementary steps in transition metal catalysis.

Incorporation of TMs into FLPs is therefore a promising objective ${ }^{4}$ and, as such, it has attracted recently considerable attention, as exemplified by the pioneering work of the groups of Wass ${ }^{5}$ and Erker ${ }^{6}$ on $\mathrm{Zr} /$ phosphine pairs and related systems. Although some TMs, in particular Pt(o) complexes, ${ }^{7}$ have been employed as Lewis base (LB) partners in FLP-like designs, no examples of transition metal-only FLPs (TMOFLPs), where both the acidic and the basic functions are constructed on TMs, seen to be known, ${ }^{8}$ despite the existence of a large number of heterobimetallic systems capable of activating small molecules in a fashion reminiscent of FLPs. ${ }^{9,10}$

Cationic $\mathrm{Au}(\mathrm{I})$ and neutral Pt(o) complexes have a well-known capacity to behave as LA and LB fragments, respectively. Hence, they were envisioned as suitable building blocks to frame an intermolecular TMOFLP. To attain frustration, triflimide $\mathrm{Au}(\mathrm{I})$ complex $\left[\mathrm{Au}\left(\mathrm{NTf}_{2}\right)\left(\mathrm{PMe}_{2} \mathrm{Ar}^{\mathrm{Dipp} 2}\right)\right](\mathbf{1}),{ }^{11}$ containing the bulky terphenyl phosphine $\mathrm{PMe}_{2} \mathrm{Ar}^{\text {Dipp2 }}\left(\mathrm{Ar}^{\text {Dipp2 }}=\mathrm{C}_{6} \mathrm{H}_{3}-2,6-\left(\mathrm{C}_{6} \mathrm{H}_{3}-\right.\right.$ 2,6- $\left.\left.{ }^{i} \mathrm{Pr}_{2}\right)_{2}\right),{ }^{12}$ and the $\mathrm{Pt}(\mathrm{o})$ species $\left[\mathrm{Pt}\left(\mathrm{P}^{t} \mathrm{Bu}_{3}\right)_{2}\right](\mathbf{2})$, were utilized as FLP constituents. The present contribution reports the results of our preliminary investigation into the activation of $\mathrm{H}_{2}$ and $\mathrm{C}_{2} \mathrm{H}_{2}$ by the resulting cationic $\mathrm{Au}(\mathrm{I}) / \mathrm{Pt}(\mathrm{o}) \mathrm{TMOFLP}$.

Although the main ${ }^{1} \mathrm{H}$ and ${ }^{31} \mathrm{P}\left\{{ }^{1} \mathrm{H}\right\}$ NMR features of complexes 1 and 2 remained unaltered when their $\mathrm{C}_{6} \mathrm{D}_{6}$ solutions were combined, upon mixing, the initially colorless solutions of 1 and 2 distinctly became bright yellow. Furthermore, in $\mathrm{CD}_{2} \mathrm{Cl}_{2}$ as the solvent, the ${ }^{31} \mathrm{P}\left\{{ }^{1} \mathrm{H}\right\}$ NMR resonances of $\mathbf{1}(-11.5 \mathrm{ppm})$ and $2(99.6 \mathrm{ppm})$ become broad, with $\omega_{1 / 2}$ values $\left(25^{\circ} \mathrm{C}\right)$ of $35^{\mathrm{and}} 28 \mathrm{o} \mathrm{Hz}$, respectively. It should be remarked that upon cooling at $-30{ }^{\circ} \mathrm{C}$, the ${ }^{31} \mathrm{P}\left\{{ }^{1} \mathrm{H}\right\}$ signals of $\mathbf{1}$ and $\mathbf{2}$ became sharp, and that no NMR line broadening with temperature was noted for separate solutions of $\mathbf{1}$ and $\mathbf{2}$. The observed changes may be attributed to establishment of the equilibrium depicted in Scheme 1 , in which adduct formation became slightly favored in the more polar, weakly coordinating solvent $\mathrm{CD}_{2} \mathrm{Cl}_{2}$, in comparison with $\mathrm{C}_{6} \mathrm{D}_{6}$. The reduced thermodynamic stability of adduct $\mathrm{A}$ relative to the individual LA and LB components can be ascribed to steric frustration and it is in sharp contrast with the reversible formation of Au/Pt LPs by insertion of $\left[\mathrm{Pt}\left(\mathrm{PC}_{3}\right)_{2}\right]$ into gold-halogen bonds, disclosed recently by Braunschweig and coworkers. ${ }^{13}$ 


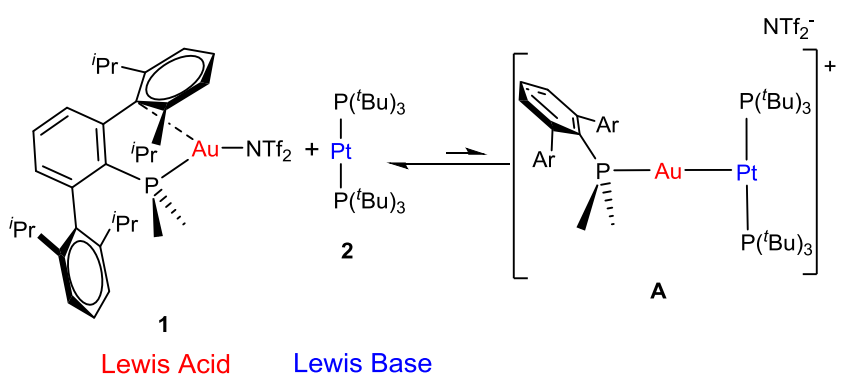

Scheme 1. Proposed solution equilibrium for TMOFLP $1 / 2$.

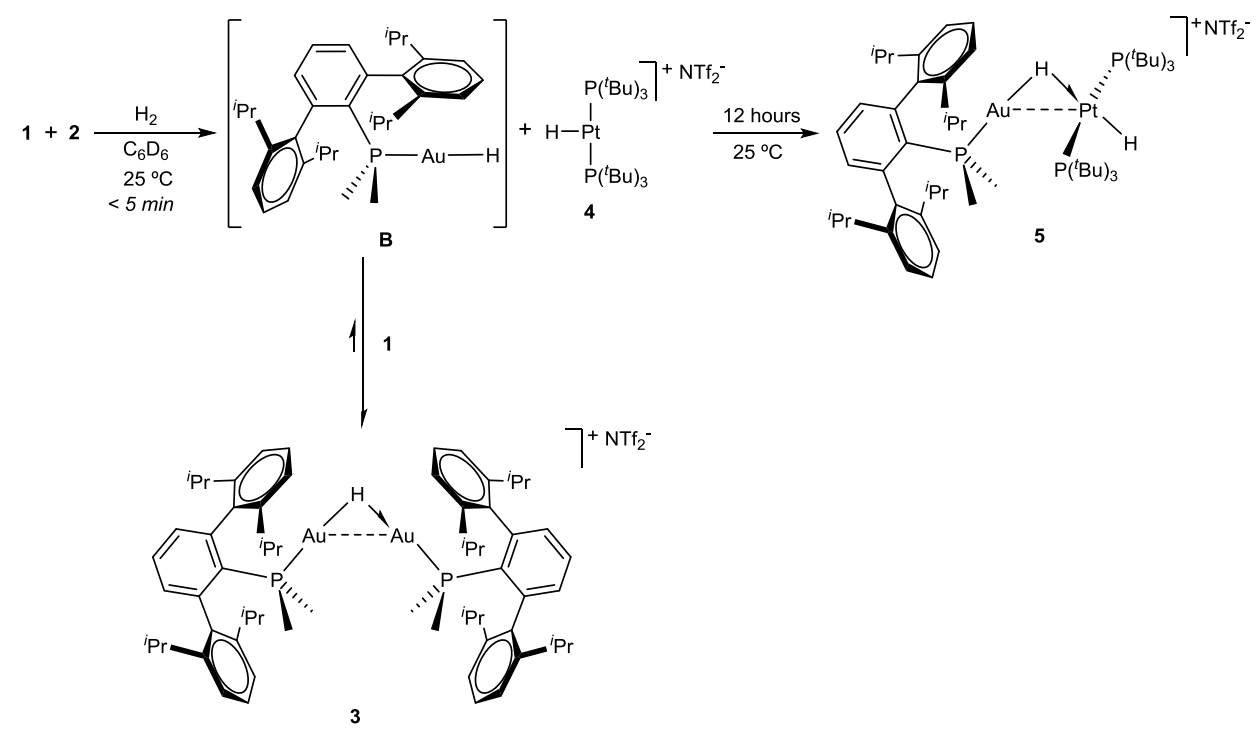

Scheme 2. Reaction of $\mathrm{Au}(\mathrm{I}) / \mathrm{Pt}(\mathrm{o})$ TMOFLP with $\mathrm{H}_{2}$.

To confirm that an equimolar mixture of complexes 1 and 2 could exhibit FLP behavior, the reactivity towards $\mathrm{H}_{2}$ and $\mathrm{C}_{2} \mathrm{H}_{2}$ was investigated. Neither complex 1 nor complex 2 yielded a reaction observable by NMR when their $\mathrm{C}_{6} \mathrm{D}_{6}$ solutions were treated with $\mathrm{H}_{2}$ (0.5 bar), even after a week of exposure. In marked contrast, a smooth, quick reaction took place ( $<5$ min) when a $\mathrm{C}_{6} \mathrm{D}_{6}$ solution of TMOFLP $1 / 2$ was subjected to $\mathrm{H}_{2}$ atmosphere (o.5 bar). Full consumption of gold complex $\mathbf{1}$ took place, leading to a 1:1:1 mixture of unreacted 2, a new hydride-bridged digold complex 3, and the known platinum hydride $4^{14}$ (Scheme 2). After around 12 hours the foregoing mixture converted into the hydride-bridged platinum-gold complex 5 , that was obtained as the only metal-containing product (ca. $95 \%$ by NMR).

The chemical constitution of complex 5 suggests it could result from an LA/LB interaction between the unsaturated platinum(II) hydride complex 4 and an unobserved neutral gold(I) hydride of formulation $\left[\mathrm{Au}(\mathrm{H})\left(\mathrm{PMe}_{2} \mathrm{Ar}^{\mathrm{Dipp}}\right)\right](\mathbf{B})$ that required about 12 hours for completion. In turn, these two species could arise from the fast $(<5 \mathrm{~min})$ heterolytic activation of $\mathrm{H}_{2}$ by the TMOFLP $\mathbf{1} / \mathbf{2}$, although the purported gold hydride $\mathbf{B}$ would be instantly trapped by still unreacted $\left[\mathrm{Au}\left(\mathrm{NTf}_{2}\right)\left(\mathrm{PMe}_{2} \mathrm{Ar}^{\text {Dipp2 }}\right)\right](\mathbf{1})$ forming reversibly the hydride-bridged digold complex 3 . This is highly reminiscent of the formation of the methyl-bridged digold analogue of complex 3 by protonation of $\left[\mathrm{Au}\left(\mathrm{CH}_{3}\right)\left(\mathrm{PMe}_{2} \mathrm{Ar}^{\text {Dipp2 }}\right)\right]$ with an excess of $\left[\mathrm{H}\left(\mathrm{OEt}_{2}\right)\right]\left[\mathrm{BAr}_{\mathrm{F}}\right]^{1 .}{ }^{11} \mathrm{The}$ structural complexity of 3 was ascertained on the basis of a distinctive ${ }^{1} \mathrm{H}$ NMR resonance with $\delta 2.83 \mathrm{ppm}$, exhibiting a two-bond coupling of $99.5 \mathrm{~Hz}$ to two chemically equivalent ${ }^{31} \mathrm{P}$ nuclei. These NMR parameters resemble closely those reported for a related complex of the biaryl phosphine $\mathrm{P}(\mathrm{tBu})_{2}$ (o-biphenyl). ${ }^{15}$ In addition, complex $\mathbf{3}$ was independently synthesized by reaction of $\mathbf{1}$ with SiHEt ${ }_{3}$, that is to say, following a general approach to $\left[\mathrm{Au}_{2}(\mu-\mathrm{H}) \mathrm{L}_{2}\right]^{+}$structural motifs (see the Supporting Information for details). ${ }^{15,16}$

For complex 5 two strongly shielded ${ }^{1} \mathrm{H}$ NMR resonances at -1.67 and $-11.39 \mathrm{ppm}$, with ${ }^{195} \mathrm{Pt}$ satellites of 503 and $1053 \mathrm{~Hz}$, respectively, can be confidently assigned to the bridging and terminal hydride ligands (see SI for other relevant NMR parameters). Observation of ${ }^{195} \mathrm{Pt}$ satellites for the gold-bound $\mathrm{PMe}_{2} \mathrm{Ar}^{\mathrm{Dipp} 2}$ ligand $\left(7.2 \mathrm{ppm},{ }^{2} J_{\mathrm{PPt}}=200 \mathrm{~Hz}\right)$ implies the existence of the heterobimetallic Au-Pt core, that was further confirmed by observation in the ${ }^{1} \mathrm{H}-{ }^{31} \mathrm{P}$ NMR correlation spectrum of cross-peaks between the bridging hydride and the two different kinds of phosphine ligands. This type of structure finds ample precedent in the literature, ${ }^{9}$ though only two $[\mathrm{Au}(\mu-\mathrm{H}) \mathrm{Pt}]^{+}$frames were authenticated by $\mathrm{X}$-ray crystallography. ${ }^{17,18}$ Figure 1 contains the solidstate molecular structure of complex 5, characterized by a Pt-Au distance of 2.848(1) $\AA$ that is somewhat longer than found for analogous compounds (ca. $2.70-2.80 \AA)^{17,18}$ and it is significantly elongated when compared to others with direct Pt-Au bonds $(2.5-2.6 \AA){ }^{13,19}$ The bulkiness of the $\mathrm{H}-\mathrm{AuPMe}_{2} \mathrm{Ar}^{\mathrm{Dipp} 2}$ unit bonded to the $\mathrm{Pt}(\mathrm{II})$ center is probably responsible for the relatively reduced $\mathrm{P}_{2}-\mathrm{Pt}_{1}-\mathrm{P}_{3}$ angle of $159.26(9)^{\circ}$. 


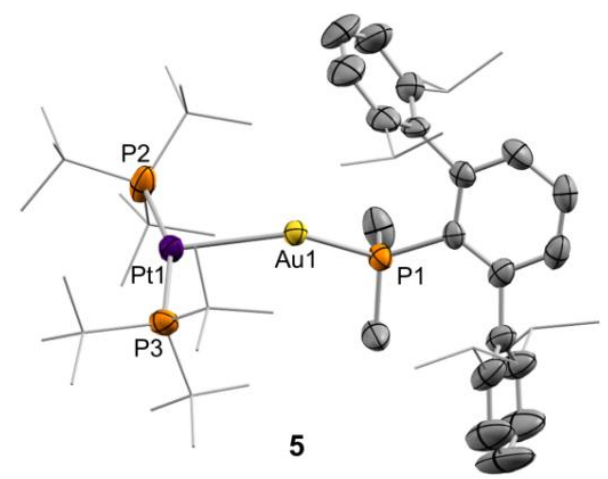

Figure 1. ORTEP diagram for compound 5. Thermal ellipsoids are drawn at the $50 \%$ probability. TM-hydrides could not be located in the difference Fourier electron density map. Counterion and hydrogen atoms omitted and tert-butyl and iso-propyl groups in wireframe format for clarity.

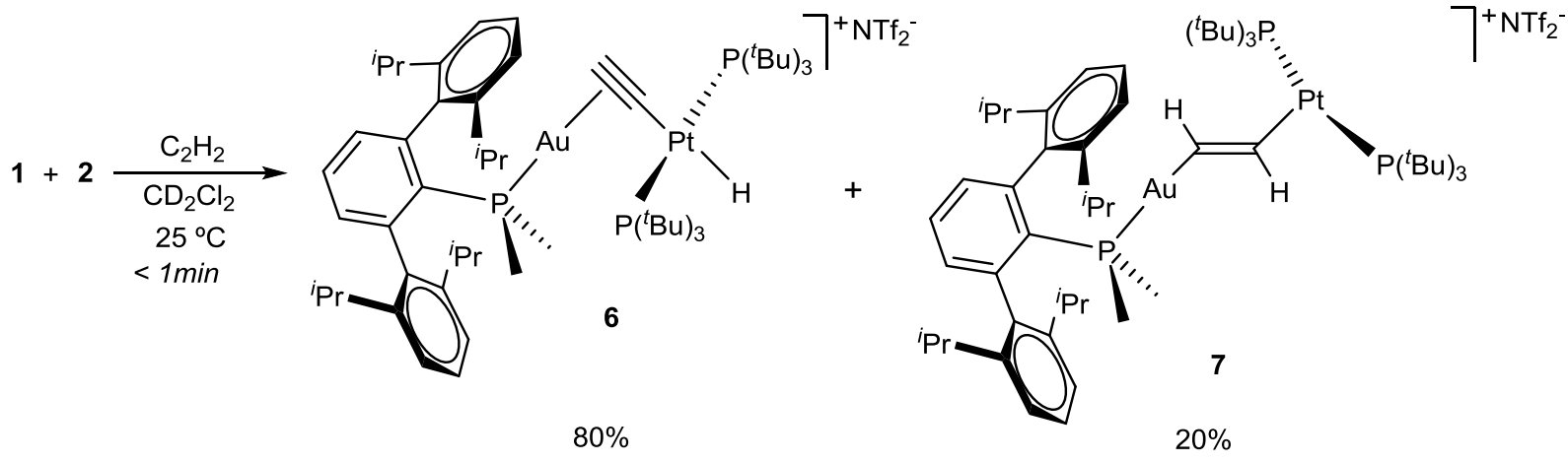

\section{Scheme 3. Reaction of TMOFLP 1:2 with $\mathrm{C}_{2} \mathrm{H}_{2}$.}

As briefly noted earlier, the reactivity of the $\mathrm{Au}(\mathrm{I}) / \mathrm{Pt}(\mathrm{o})$ FLP against $\mathrm{C}_{2} \mathrm{H}_{2}$ was also inspected. Before discussing it, it is important to note that complex 1 underwent no NMR observable reaction with acetylene, whereas 2 promoted instantly catalytic polymerization of $\mathrm{C}_{2} \mathrm{H}_{2}$, originating a purple-black solid while remaining spectroscopically unchanged. At variance with these observations, exposure of benzene solutions of the $\mathrm{Au}(\mathrm{I})$ and $\mathrm{Pt}(\mathrm{o})$ complexes $\mathbf{1}$ and $\mathbf{2}$ to $\mathrm{C}_{2} \mathrm{H}_{2}$, resulted in an instantaneous color change from bright yellow to intense orange, with no formation of purple-black polyacetylene solid. Rather, NMR monitoring revealed fast, full consumption of $\mathbf{1}$ and $\mathbf{2}$, and formation of two isomeric, albeit structurally distinct, products, namely $\left[\left(\mathrm{PMe}_{2} \mathrm{Ar}^{\text {Dipp } 2}\right) \mathrm{Au}\left(\mu-\eta^{2}: \eta^{1}-\mathrm{C} \equiv \mathrm{CH}\right) \mathrm{Pt}(\mathrm{H})\left(\mathrm{P}^{t} \mathrm{Bu}_{3}\right)_{2}\right]^{+}(\mathbf{6})$ and $\left[\left(\mathrm{PMe}_{2} \mathrm{Ar}^{\text {Dipp } 2}\right) \mathrm{Au}\left(\mu-\eta^{1}: \eta^{1}-\mathrm{CH}=\mathrm{CH}\right) \mathrm{Pt}(\mathrm{H})\left(\mathrm{P}^{t} \mathrm{Bu}_{3}\right)_{2}\right]^{+}(\mathbf{7})$. As represented in Scheme 3, the two compounds formed in a ca 4:1 ratio. As this proportion remained unchanged with time and upon heating at $90{ }^{\circ} \mathrm{C}$, it is clear that complexes 6 and 7 stemmed from competitive, independent reaction paths.

Complex 6 possesses a bridging $\sigma, \pi$-acetylide ligand $\pi$-bonded to a cationic $\mathrm{Au}(\mathrm{I})$ center and $\sigma$-bonded to a Pt(II) hydride fragment, whereas in 7 the two metals are held together by a $\mu$-ethene-1,2-diyl linker through two M-C $\sigma$ bonds. This reaction outcome resembles alkyne activation by conventional FLPs, for which alkyne deprotonation or addition may be operative, depending mainly on the basicity of the LB moiety. ${ }^{20}$ The nature of complex 7 bears a likeness with classic FLP addition products, or in a different context, with the product of attacking a $\mathrm{Au}(\mathrm{I})$ activated molecule of acetylene with a Pt(o) nucleophile. Although generation of a structure of type 6 from $\mathrm{C}_{2} \mathrm{H}_{2}$ is, in a way, reminiscent of FLP alkyne deprotonation, it is exclusive of alkyne activation by this TMOFLP. Alkyne deprotonation by main group FLPs typically leads to $\left[\mathrm{R}_{3} \mathrm{PH}\right]\left[\mathrm{R}^{\prime} \mathrm{C} \equiv \mathrm{CBAr} \mathrm{r}_{3}\right]$ products which are devoid of P-B interactions and have the LA component $\sigma$-bonded to the acetylide function.

The molecular structure of $\mathbf{6}$ and $\mathbf{7}$ was inferred from NMR and X-ray studies. Complex $\mathbf{6}$ was isolated in microanalytically pure form but crystals of the minor isomer 7 could only be obtained from co-crystallized mixtures of the two compounds after anion exchange with $\mathrm{BAr}_{\mathrm{F}}{ }^{-}$and were separated by hand under the microscope for X-ray crystallographic analysis. NMR data for the latter compound were recorded from these mixtures. Some characteristic NMR parameters for $\mathbf{6}$ and 7 follow; other data are collected in the accompanying Supporting Information. Both the $\mathrm{P}^{t} \mathrm{Bu}_{3}$ and $\mathrm{PMe}_{2} \mathrm{Ar}^{\mathrm{Dipp} 2}$ ligands of the two complexes show similar ${ }^{31} \mathrm{P}\left\{{ }^{1} \mathrm{H}\right\}$ chemical shifts, recorded at 82.8 and $81.7(\mathrm{Pt}-\mathrm{P})$, and -0.1 and 2.1 ppm (Au-P), respectively. In full agreement with the structure proposed for complex 7, the latter Au-P signal displays typical satellites arising from a four-bond ${ }^{31} \mathrm{P}-{ }^{195} \mathrm{Pt}$ coupling of $282 \mathrm{~Hz}$. In addition, its bridging vinylene (- $\mathrm{HC}=\mathrm{CH}-)$ linker renders distinctive ${ }^{1} \mathrm{H}$ NMR resonances at 4.34 and $4.04 \mathrm{ppm}$, with $J_{\mathrm{HPt}}$ values of 118 and $196 \mathrm{~Hz}$, respectively, and corresponding ${ }^{13} \mathrm{C}$ signals at $115.3\left({ }^{1} J_{\mathrm{CH}}=189 \mathrm{~Hz}\right)$ and $155.1 \mathrm{ppm}\left({ }^{1} J_{\mathrm{CH}}=151 \mathrm{~Hz}\right)$.

The Pt-H terminus of major isomer 6 displays a shielded ${ }^{1} \mathrm{H}$ NMR resonance with $\delta-10.4 \mathrm{ppm}\left({ }^{1} J_{\mathrm{HPt}}=559 ;{ }^{2} J_{\mathrm{HP}}=28.2 \mathrm{~Hz}\right)$, whereas the $\mathrm{H}$ atom of the bridging $-\mathrm{C} \equiv \mathrm{CH}$ ligand appears at $2.39 \mathrm{ppm}$, showing ${ }^{3} J_{\mathrm{HP}}$ and ${ }^{3} J_{\mathrm{HPt}}$ couplings of 6.6 and $36.1 \mathrm{~Hz}$, respectively. The corresponding ${ }^{13} \mathrm{C}$ signals are found at 128.6 and 108.7 , the latter exhibiting a characteristic ${ }^{1} J_{\mathrm{CH}}$ coupling constant of $240 \mathrm{~Hz}$. At variance with the homometallic complex $\left[\mathrm{Au}_{2}(\mu-\sigma, \pi-\mathrm{C} \equiv \mathrm{CH}) \mathrm{PMe}_{2} \mathrm{Ar}^{\mathrm{Dipp}}\right]^{+}$that undergoes fast exchange of the gold atom environments, ${ }^{11}$ the heterobimetallic complex 6 shows no hints of fluxionality. 
Figure 2 contains perspective views of the molecular structures of complexes 6 and 7. The former possesses a bridging acetylide ligand $\sigma$-bonded to platinum with a Pt-C distance of 2.044(7) Å, and $\pi$-bound to the cationic Au(I) center, with Au1$C_{57}$ and Au1- $C_{5} 8$ separations of 2.36o(7) and 2.162(8) $\AA$, respectively. The latter are similar to analogous interactions in $\left[\mathrm{Au}_{2}(\mu-\right.$ $\left.\mathrm{C} \equiv \mathrm{CH})\left(\mathrm{PMe}_{2} \mathrm{Ar}^{\mathrm{Dipp} 2}\right)\right]^{+}{ }^{11}$. The steric pressure exercised by the gold moiety probably distorts the coordination of the platinum to the observed pleated geometry, constraining the supposedly trans $\mathrm{P}_{2}-\mathrm{Pt1}-\mathrm{P}_{3}$ distribution from the ideal ${ }_{180^{\circ}}$ angle to ${ }_{158.85}(9)^{\circ}$. With reference to the bimetallic vinylene complex 7 , the Au1- $\mathrm{C}_{57}-\mathrm{C}_{5} 8-\mathrm{Pt}$ t atom assortment is nearly planar, with a torsion angle of $178.3(8)$, , therefore very close to the ideal geometry. The two Au1-C 57 and $\mathrm{Pt}_{1}-\mathrm{C}_{5} 8 \sigma$ bonds have normal values for this kind of structure $\left(2.043(8)\right.$ and $2.001(8) \AA$, respectively). Similarly, the relatively short $C_{57}-C_{5} 8$ bond length of $1.287(11) \AA ̊$, albeit shorter than typical $\mathrm{C}=\mathrm{C}$ bonds, is also akin to reported values for a related complex. ${ }^{21}$ Another relevant structural property of complex 7 which is worthy of note is the three-coordinate, T-shape geometry of its cationic Pt(II) center, in which the free coordination site is trans to the Pt-alkenyl $\sigma$ bond, and the P-Pt-P bond angle spans 168.74(9)‥
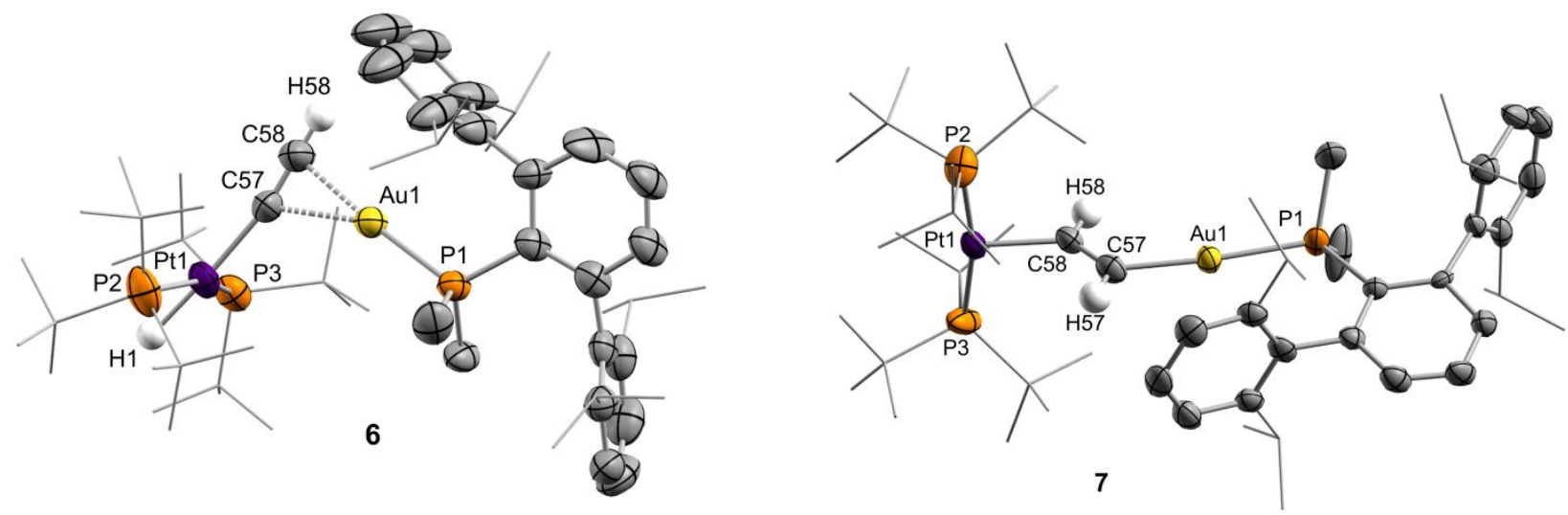

Figure 2. ORTEP diagrams for complexes 6 and 7. Thermal ellipsoids are drawn at the 50 \% probability. Counterions and most hydrogen atoms omitted and tert-butyl and iso-propyl groups in wireframe format for clarity.

In summary, from the results of this work it can be concluded that the combination of two sufficiently bulky transition-metalbased fragments of acidic and basic Lewis character can quench Lewis adduct formation ${ }^{22}$ and confer high potential for small molecule activation. When in conjunction, $\mathrm{Au}(\mathrm{I})$ and $\mathrm{Pt}(\mathrm{o})$ complexes 1 and $\mathbf{2}$ with sterically hindered coordination environments, activate $\mathrm{H}_{2}$ and $\mathrm{C}_{2} \mathrm{H}_{2}$ under mild conditions whereby the individual complexes are unreactive. It has, therefore, been demonstrated for the first time that TMOFLPs are indeed viable, accessible entities, that may be exploited to attain valuable reactivity, taking advantage of the unique electronic properties of the two TM components. As a result, uncommon heterobimetallic $\mathrm{Au}(\mathrm{I}) / \mathrm{Pt}(\mathrm{II})$ complexes with hydride, acetylide and vinylene bridging ligands have been isolated.

\section{ACKNOWLEDGMENT}

J.C. thanks the EU H202o Program for a Marie Skłodowska-Curie Individual Fellowship (Grant Agreement no. 706oo8). Prof. Ernesto Carmona is gratefully acknowledged for valuable advice and support.

\section{REFERENCES}

(1) (a) Stephan, D. W.; Erker, G. Angew. Chem. Int. Ed. 2015, 54, 640o; (b) Stephan, D. W.; Erker, G. Top. Curr.Chem. 2013, 334, 1; (c) Stephan, D. W.; Erker, G. Top. Curr. Chem. 2o13, 332, 1. (d) Stephan, D. W.; Erker, G. Angew. Chem. Int. Ed. 2o10, 49, 46. (e) Stephan, D. W. J. Am. Chem. Soc. 2015, 137, 10018. (f) Stephan, D. W. Science, 2016, 354, 1248.

(2) Stephan, D. W. Dalton Trans. 2009, 3129. (b) Stephan, D. W. Org. Biomol. Chem. 2012, 10, 5740. (c) Stephan, D. W. Acc. Chem. Res. 2015, $48,306$.

(3) (a) Courtemanche, M. A.; Légaré, M. A.; Maron, L.; Fontaine, F. G. J. Am. Chem. Soc. 2013, 135, 9326. (b) Wang, T.; Stephan, D. W. Chem. Eur. J. 2014, 20, 3036. (c) Mahdi, T.; Stephan, D. W. Angew. Chem. Int. Ed. 2013, 52, 12418. (d) Mo, Z.; Rit, A.; Campos, J.; Kolychev, E. L.; Aldridge, S. J. Am. Chem. Soc. 2016, 138.

(4) Flynn, S. R.; Wass, D. F. ACS Catal. 2013, 3, 2574.

(5) (a) Chapman, A. M.; Haddow, M. F.; Wass, D. F. Eur. J. Inorg. Chem. 2012, 9, 1546. (b) Metters, O. J.; Forrest, S. J. K.; Sparkes, H. A.; Manners, I.; Wass, D. F. J. Am. Chem. Soc. 2016, 138, 1994. (c) Chapman, A. M.; Haddow, M. F.; Wass, D. F. J. Am. Chem. Soc. 2011, 133, 8826. (d) Flynn, S. R.; Metters, O. J.; Manners, I.; Wass, D. F. Organometallics 2016, 35, 847. (e) Metters, O. J., Flynn, S. R., Dowds, C. K., Sparkes, H. A., Manners, I., Wass, D. F. ACS Catal. 2016, 6, 6601.

(6) (a) Erker, G. Dalt. Trans. 2011, 40, 7475. (b) Xu, X.; Kehr, G.; Daniliuc, C. G.; Erker, G. Angew. Chem. Int. Ed. 2013, 52, 13629. (c) Xu, X.; Kehr, G.; Daniliuc, C. G.; Erker, G. J. Am. Chem. Soc. 2o13, 135, 6465. (d) Normand, A. T.; Richard, P.; Balan, C.; Daniliuc, C. G.; Kehr, G.; Erker, G.; Le Gendre, P. Organometallics 2015, 34, 200o. (e) Normand, A. T.; Daniliuc, C. G.; Wibbeling, B.; Kehr, G.; Le Gendre, P.; Erker, G. J. Am. Chem. Soc. 2015, 137, 10796. (f) Hasegawa, Y.; Kehr, G.; Ehrlich, S.; Grimme, S.; Daniliuc, C. G.; Erker, G. Chem. Sci. 2014, 5, 797. (g) Xu, X.; Kehr, G.; Daniliuc, C. G.; Erker, G. Organometallics 2015, 34, 2655.

(7) (a) Forrest, S. J. K.; Clifton, J.; Fey, N.; Pringle, P. G.; Sparkes, H. A.; Wass, D. F. Angew. Chem. Int. Ed. 2015, 54, 2223. (b) Barnett, B. R.; Moore, C. E.; Rheingold, A. L.; Figueroa, J. S. J. Am. Chem. Soc. 2014, 136, 10262. (c) Devillard, M.; Declercq, R.; Nicolas, E.; Ehlers, A. W.; Backs, J.; Saffon-Merceron, N.; Bouhadir, G.; Slootweg, J. C.; Uhl, W.; Bourissou, D. J. Am. Chem. Soc. 2016, 138, 4917. (d) Bauer, J.; Braunschweig, H.; Dewhurst, R. D.; Radacki, K. Chem. Eur. J. 2013, 19, 8797. (e) Barnett, B. R.; Figueroa, J. S. Chem. Commun. 2016, $52,13829$.

(8) Chapman, A. M.; Flynn, S. R.; Wass, D. F. Inorg. Chem. 2016, 55, 1017. 
(9) For selected reviews on heterobimetallic compounds see: (a) Buchwalter, P.; Rose, J.; Braunstein, P. Chem. Rev. 2015, 115, 28. (b) Ritleng, V.; Chetcuti, M. J. Chem. Rev. 2007, 107, 797. (c) Cooper, B. G.; Napoline, J. W.; Thomas, C. M. Catal. Rev. 2012, 54, 1. (d) Wheatley, N.; Kalck, P. Chem. Rev. 1999, 99, 3379.

(10) For recent examples see: (a) Riddlestone, I. M.; Rajabi, N. A.; Lowe, J. P.; Mahon, M. F.; Macgregor, S. A.; Whittlesey, M. K. J. Am. Chem. Soc. 2016, 138, 11081. (b) Karunananda, M. K.; Mankad, N. P. J. Am. Chem. Soc. 2o15, 137, 14598. (c) Zhang, Y.; Roberts, S. P.; Bergman, R. G.; Ess, D. H. ACS Catal. 2015, 5, 1840. (d) Mazzacano, T. J.; Mankad, N. P. J. Am. Chem. Soc. 2013, 135, 17258. (e) Parmelee, S. R.; Mazzacano, T. J.; Zhu, Y.; Mankad, N. P.; Keith, J. A. ACS Catal. 2015, 5, 3689.

(11) Espada, M. F.; Campos, J.; López-Serrano, J.; Poveda, M. L.; Carmona, E. Angew. Chem., Int. Ed. 2015, 54, 15379.

(12) (a) Ortega-Moreno, L.; Fernández-Espada, M.; Moreno, J. J.; Navarro-Gilabert, C.; Campos, J.; Conejero, S.; López-Serrano, J.; Maya, C.; Peloso, R.; Carmona, E. Polyhedron 2016, 116, 17o. (b) Campos, J.; Ortega-Moreno, L.; Conejero, S.; Peloso, R.; López-Serrano, J.; Maya, C.; Carmona, E. Chem. Eur. J. 2015, 21, 8883. (c) Ortega-Moreno, L.; Peloso, R.; Maya, C.; Suárez, A.; Carmona, E. Chem. Commun. 2015, 51, 17008.

(13) Bauer, J.; Braunschweig, H.; Damme, A.; Radacki, K. Angew. Chem. Int. Ed. 2012, 51, 10030.

(14) Goel, R. G.; Srivastana, R. C. Can. J. Chem. 1983, 61, 1352.

(15) Harris, R. J.; Widenhoefer, R. A. Angew. Chem. Int. Ed. 2014, 53, 9369.

(16) (a) Tsui, E. Y.; Mller, P.; Sadighi, J. P. Angew. Chem. Int. Ed. 2oo8, 47, 8937. (b) Escalle, A.; Mora, G.; Gagosz, F.; Mezailles, N.; Le Goff, X. F.; Jean, Y.; Le Floch, P. Inorg. Chem. 2009, 48, 8415.

(17) Albinati, A.; Lehner, H.; Venanzi, L. M.; Wolfer, M. Inorg. Chem. 1987, 26, 3933.

(18) Crespo, M.; Sales, J.; Solans, X. J. Chem. Soc. Dalton Trans. 1989, 1089.

(19) (a) Shan, H.; James, A.; Sharp, P. R. Inorg.Chem. 1998, 37, 5727. (b) Batten, S. A.; Jeffery, J. C.; Jones, P. L.; Mullica, D. F.; Rudd, M. D.; Sappenfield, E. L.; Stone, F. G. A.; Wolf, A. Inorg.Chem. 1997, 36, 2570. (c) de Silva, N.; Laufenberg, J. W.; Dahl, L. F. Chem Commun. 20o6, 4437. (e) Douglas, G.; Jennings, M. C.; Manojlovic-Muir, L.; Puddephatt, R. J. Inorg.Chem. 1988, 27, 4516.

(20) (a) Dureen, M. A.; Stephan, D. W. J. Am. Chem. Soc. 2009, 131, 8396. (b) Dureen, M. A.; Brown, C. C.; Stephan, D. W. Organometallics 2010, 29, 6594. (c) Fukazawa, A.; Yamada, H.; Yamaguchi, S. Angew. Chem. Int. Ed. 20o8, 47, 5582. (d) Geier, S. J.; Dureen, M. A; Ouyang, E. Y.; Stephan, D. W. Chem. Eur.J. 2010, 16, 988.

(21) Steinborn, D.; Aisa, A. M. A.; Heinemann, F. W.; Lehmann, S. J. Organomet. Chem. 1997, 527, 239.

(22) Bauer, J.; Braunschweig, H.; Dewhurst, R. D. Chem. Rev. 2012, 112, 4329. 